\title{
A Relapsing Polychondritis and Malignancies: A Case Report and Review of Literature
}

\author{
Ben Salah Raida*, Cherif Yosra, Frikha Faten, Snoussi Mouna, Jallouli \\ Moez, Marzouk Sameh and Bahloul Zouhir
}

Department of Internal Medicine, HediChaker university hospital, Tunisia

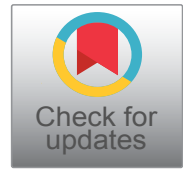

*Corresponding author: Raida Ben Salah, Department of Internal Medicine, Hedi Chaker university hospital, Sfax, Tunisia, Tel: 21696642143, E-mail: raidabensalah@yahoo.fr

\begin{abstract}
Some case reports and series presumed a link between malignancy and relapsing polychondritis. The most frequent described neoplasms have been hematological disorders especially myelodysplastic syndromes. Less commonly have also been reported solid neoplasms as colorectal cancer like our patient. We suggest that patients with RP should be monitored more carefully even in remission for early detection of cancer.
\end{abstract}

\section{Introduction}

Relapsing polychondritis (RP) is an uncommon systemic disease which is characterized by recurrent inflammation of cartilaginous tissues, including the ears, nose, laryngotracheobronchial tree, and peripheral joints. Evidence for a significant RP-cancer association is uncommon [1]. Some case reports and series presumed a link between malignancy and RP. About 85 cases of RP associated with malignancies have been reported in the literature [2].

The most frequent described neoplasms have been hematological disorders especially myelodysplastic syndromes [1]. Less commonly solid neoplasms have also been reported [2]. Although it has been noted that RP may occur with colic cancer, colorectal cancer associated with RP remains scarce.

We present a patient with chronic RP that developed acolorectal cancer 12 years later and we reviewed all cases reported in literature.

\section{Case Report}

A 56-year-old man was admitted in June 2012 to our department of Internal Medicine complaining of progressive weakness and dyspnae for about 3 weeks. His medical history was noteworthy of recurrent uveitis. He had hoarseness and intermittent breathlessness for greater than 9 years. At that time, there were no fever, night sweating. He was admitted repeatedly in the department of Otorhinolaryngology. A bronchoscopy showed a subglottic stenosis. The patient experienced further dyspnea, so emergency tracheostomy was performed.

The patient was treated with inhaled corticosteroids and betaagonists for bronchial asthma, without a significant improvement thereafter. He reported recurrent swelling and tenderness of both ears.
On admission to our department, physical examination revealed thickening of both external ears with erythema of the auricles with a saddle-nose. Fine rales over both lower lung fields were heard. Ophtalmological examination revealed bilateral anterior uveitis.

Computed tomography of the chest disclosed stenosis of the trachea, swelling of cartilages and bilateral main bronchus (Figure 1).

All the laboratory data was with the normal range. Antinuclear antibody was negative. Auricle biopsy showed a lymphocytic infiltration around the blood vessels, which is compatible with RP. Given that our patient has recurrent chondritis of auricles, nasal cartilage and the upper respiratory tract, recurrent uveitis, the diagnosis of RP was made and the patient was treated with Prednisone: $30 \mathrm{mg} /$ day for 3 weeks and the dose of prednisone was tapered with no relapse.

He was admitted 3 years after for acute rectal bleeding. The pulse rate was 110 per minute, and his blood pressure was $110 / 70 \mathrm{mmHg}$. He stated that he lost $10 \mathrm{Kg}$ in weight 2 months before. Besides, he complained of lower abdominal pain and bloody diarrhea.Laboratory studies revealed anemia at $6.9 \mathrm{~g} / \mathrm{dl}$, the leukocyte count: $5690 / \mathrm{mm}^{3}$, the platelets count: $423000 / \mathrm{mm}^{3}$. Serum electrolytes, creatinine and liver tests were with the normal range. The stool culture was negative.

Tumor markers were checked: PSA were normal but he had marked elevation of CEA, CA19-9 markers of up to $325 \mathrm{ng} / \mathrm{ml}$. The patient was transfused. Abdominal computed tomography revealed a thickness of the descending colon wall, a liver mass on the right lobe and a necrotic adenopathy (Figure 2). Colonoscopy revealed an ulcer formation and bleeding from the sigmoid colon. Colic tumor specimen showed undifferentiated adenocarcinoma. An extended right colectomy was performed. A subsequent chemotherapy was administrated. He was discharged and still receiving Prednisone: 10 $\mathrm{mg}$ /day without flare-up of RP.

\section{Discussion}

$\mathrm{RP}$ is a rare recurrent inflammatory diseasethat affects cartilaginous tissue, especially the ear, nose and tracheobronchial cartilage $[1,3]$.

Our patient, having recurrent chondritis and chronic uveitis fulfilled the diagnosis criteria of Michet [1] in the absence of evidence of other disease.

Citation: Raida BS, Yosra C, Faten F, Mouna S, Moez J, et al. (2016) A Relapsing Polychondritis and Malignancies: A Case Report and Review of Literature. J Dermatol Res Ther 2:041

Received: October 20, 2016: Accepted: December 15, 2016: Published: December 17, 2016 Copyright: ( 2016 Raida BS, et al. This is an open-access article distributed under the terms of the Creative Commons Attribution License, which permits unrestricted use, distribution, and reproduction in any medium, provided the original author and source are credited. 

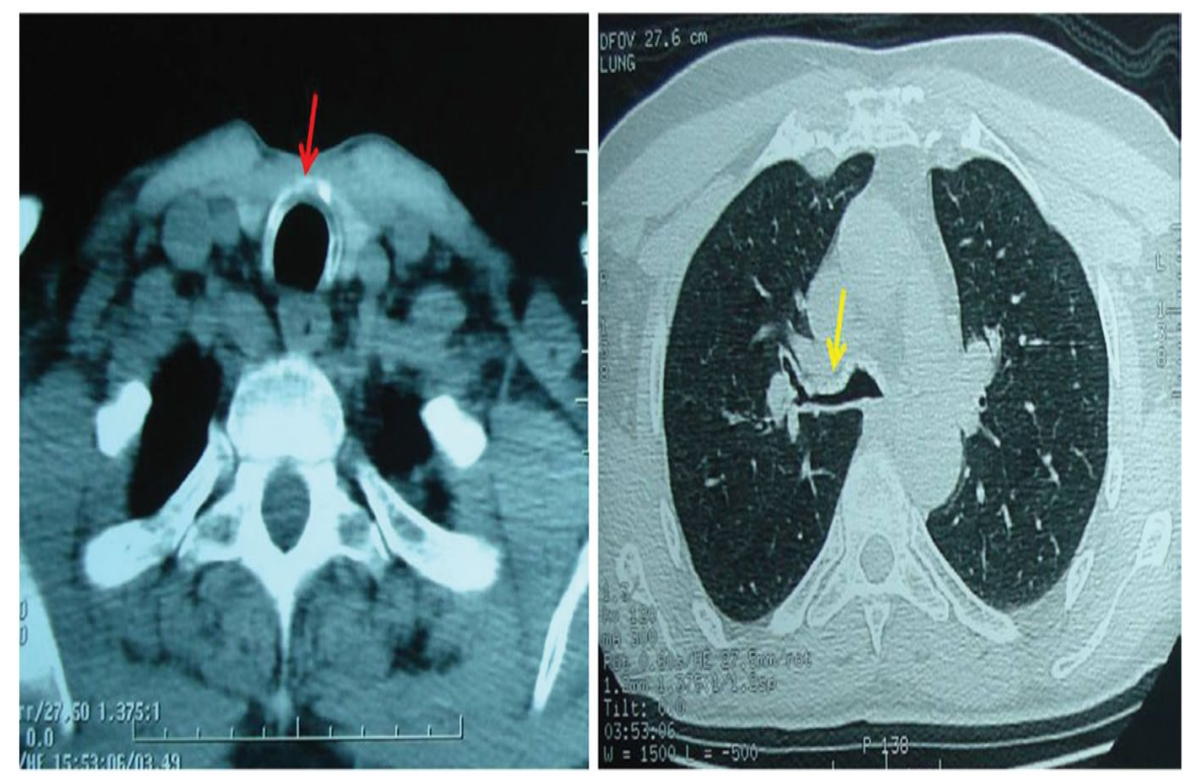

Figure 1: Stenosis of the trachea, swelling of cartilages and bilateral main bronchus.

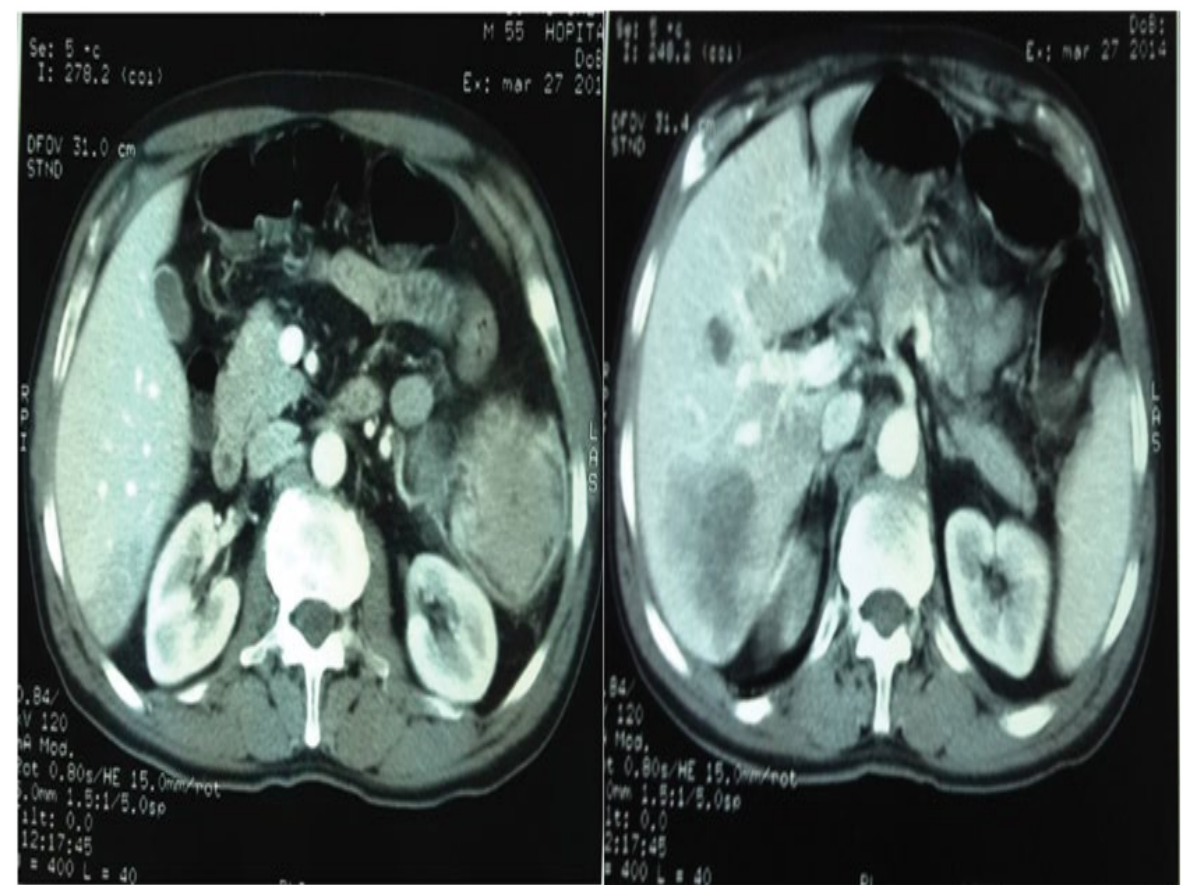

Figure 2: Huge thickness of the descending colon wall, multiple liver masses on the right lobe and a necrotic adenopathy.

Many associated autoimmune diseases, connective tissue diseases, vasculitis and hematologic disorders have been described in one third of patients [1]. Less frequently, RP has been associated with solid neoplasms [2].

It is interesting that RP has a significant association with malignancy. Our review of the recent literature showed that this association is not uncommon. Table 1 summarizes 87 cases of malignancy associated with RP in patients previously reported in literature. Most instances occur, in man at the age of 30-year-old [26-79 years] (Table 1). The most cases concluded that there is an increased relative risk of malignancy in RP with old age, like our patient. The cases largely occurred in men with a male/female ratio was 4.5 [details available only for 46 cases].

The diagnosis of neoplasm was often established after RP in 10 cases with a mean duration of 30 months ( 2 months- 11 year)], before $\mathrm{RP}$ with a preceding term of 18 months ( 3 weeks-36 months). RP and cancer occurred at the same time in 8 cases. The disease was active in 12 cases (Table 1 ).
This review of the literature reveals that the most frequent associated neoplasmsare the hematological disorders, mainly the myelodysplastic syndrome (MS) (Table 1). About 58 cases were recorded in the literature (Table 1). In fact, Michet, et al. [4] described 112 cases of RP, amongst whom 3 patients developed MS. In addition, Diebold, et al. [5] reported 3 cases among 19 with MS associated with RP. Moreover, Frances, et al. [6] studied 200 cases of RP and reported 22 associated MS. The rate was else high in the series of Hebbar, et al.: $28 \%$ of RP patients presented with MS [7].

Other hematological malignancies have been reported in association with RP: leukemia has been found 11 cases [4,8-10], nonHodgkin lymphoma in 6 cases $[8,11-14]$, multiple myeloma $[6,15,16]$, myeloproliferative disorders and Hodgkin disease $[14,17,18]$ in respectively 3,3 and 2 cases (Table 1).

Less commonly, cancer-related RP has been observed in patients with solid tumors. The association of colic cancer with RP is rather uncommon and detected previously in 3 patients $[19,20]$. Gning $\mathrm{SB}$, et al. [21] recorded only one case of rectal cancer with RP in a 
Table 1: Review of cancer associated with RP.

\begin{tabular}{|c|c|c|c|c|c|c|c|}
\hline Case & Year & Number & $\begin{array}{l}\text { Age of PCA } \\
\text { onset } \\
\text { (years) }\end{array}$ & Site of malignancy & Other associated disorders & $\begin{array}{l}\text { Term cancer } \\
\text { onset }\end{array}$ & PCA activity \\
\hline Michet CJ, et al. [4] & 1986 & 9 & - & $\begin{array}{l}\text { Colic adenocarcinoma } \\
\text { Myelodysplastic syndrome } \\
\text { Acute myelogenous leukemia } \\
\text { Chronic myelogenous leukemia } \\
\text { Myeloproliferative disorder } \\
\text { Breast cancer } \\
\text { Lung cancer }\end{array}$ & - & - & - \\
\hline Diebold L, et al. [5] & 1995 & 3 & $56 /-$ & Myelodysplastic syndrome & - & 1 year after & - \\
\hline Frances C, et al. [6] & 2001 & 22 & $\begin{array}{l}18 \mathrm{M} / 4 \mathrm{~F} \\
\text { mean } \\
\text { age:63 } \\
1 \mathrm{M} / 1 \mathrm{~F} \\
\text { Mean age: } \\
61\end{array}$ & $\begin{array}{l}\text { Myelodysplastic syndrome } \\
\text { IgA myeloma }\end{array}$ & $\begin{array}{l}\text { "Sweet syndrome, vasculitis, } \\
\text { thrombosis, panniculits, } \\
\text { dermatomyositis } \\
\text { "Urticarial papules }\end{array}$ & - & - \\
\hline Hebbar M, et al. [7] & 1995 & 5 & - & Myelodysplastic syndrome & - & - & - \\
\hline Arlet $P$, et al. [8] & 1989 & 3 & - & $\begin{array}{l}\text { Myelodysplastic syndrome } \\
\text { Non-Hodgkin's lymphoma } \\
\text { Chronic myelogenous leukemia }\end{array}$ & - & - & - \\
\hline Mongin $\mathrm{M}$, et al. [9] & 1988 & $\begin{array}{l}11 \\
1\end{array}$ & - & $\begin{array}{l}\text { Myelodysplastic syndrome } \\
\text { Chronic myelogenous leukemia } \\
\text { Myeloproliferative disorder } \\
\text { Unknown primary adenocarcinoma } \\
\text { Lung cancer }\end{array}$ & - & - & - \\
\hline Hamidou MA, et al. [10] & 2000 & 2 & $-/-$ & $\begin{array}{l}\text { Myelodysplastic syndrome } \\
\text { Chronic lymphocytic leukemia }\end{array}$ & - & - & - \\
\hline Hedayati $\mathrm{H}$, et al. [11] & 1993 & 1 & $63 / \mathrm{M}$ & Non-Hodgkin's lymphoma & Pyoderma gangrenosum & Concomitant & - \\
\hline Lichauco JJ, et al. [12] & 2000 & 1 & $41 / F$ & Orbital MALT-Type lymphoma & - & 11 years after & Active disease \\
\hline Yanagi T, et al. [13] & 2007 & 1 & $60 / F$ & Splenic lymphoma & Nonspecific colitis & 3 years before & \\
\hline Krikorian JG, et al. [14] & 1997 & 1 & $41 / \mathrm{M}$ & $\begin{array}{l}\text { Hodgkin's disease } \\
\text { Acute } \\
\text { erythroleukemia }\end{array}$ & Hypothyroidism & 21 years before & Remission \\
\hline Hall $R$, et al. [15] & 2000 & 1 & $72 / \mathrm{M}$ & $\begin{array}{l}\text { Smouldering non-secretory } \\
\text { myeloma, myelodysplastic } \\
\text { syndrome }\end{array}$ & - & 5 months before & Active disease \\
\hline Morell S, et al. [16] & 2002 & 1 & $72 / \mathrm{M}$ & Multiple myeloma & Centrifugal annular erythema & 1 year before & - \\
\hline Miller SB, et al. [17] & 1974 & 1 & - & Hodgkin's disease & - & - & - \\
\hline Zeuner M, et al. [18] & 1997 & 1 & $-/-$ & Myeloproliferative disorder & - & - & - \\
\hline Jouanique C, et al. [19] & 1989 & 1 & - & $\begin{array}{l}\text { Colic adenocarcinoma } \\
\text { Malignant fibrohistiocytoma } \\
\text { Vocal cords }\end{array}$ & - & - & - \\
\hline Quinsat D, et al. [20] & 1989 & 2 & - & Colic cancer & - & - & - \\
\hline Gning SB, et al. [21] & 2001 & 1 & $30 / F$ & Rectum adenocarcinoma & $\begin{array}{l}\text { Musculo- } \\
\text { aponeurotic fibromatosis }\end{array}$ & 5 years after & Remission \\
\hline Horai Y, et al. [22] & 2011 & 1 & $72 / \mathrm{M}$ & Lung adenocarcinoma & $\begin{array}{l}\text { Auricular } \\
\text { cartilage infiltration of } \\
\text { immunoglobulin G4-positive } \\
\text { plasma cells }\end{array}$ & 3 months after & Active \\
\hline Odkuist L [23] & 1970 & $\begin{array}{l}1 \\
1\end{array}$ & $\begin{array}{l}80 / \mathrm{M} \\
72 / \mathrm{M}\end{array}$ & $\begin{array}{l}\text { Pancreas cancer } \\
\text { Prostatic cancer }\end{array}$ & - & $\begin{array}{l}6 \text { months after } \\
4 \text { years after }\end{array}$ & $\begin{array}{l}\text { Remission } \\
\text { Remission }\end{array}$ \\
\hline Manghani MK, et al. [24] & 2004 & 1 & 26/M & Kaposi's sarcoma & - & 3 months after & Active disease \\
\hline Fransen HR, et al. [25] & 1995 & 1 & - & Chondrosarcoma & - & - & - \\
\hline Astudillo L, et al. [26] & 2004 & 1 & $77 / M$ & Urothelial carcinoma & Sweet's syndrome & 2 years before & - \\
\hline Washio K, et al. [27] & 2011 & 1 & $55 / \mathrm{M}$ & Myelodysplastic syndrome & Sweet's syndrome & 6 months after & Active disease \\
\hline Kawakami T, et al. [28] & 2008 & 1 & $81 / \mathrm{M}$ & $\begin{array}{l}\text { Myelodysplastic syndrome } \\
\text { Acute myelogenous leukaemia }\end{array}$ & $\begin{array}{l}\text { Sweet's syndrome } \\
\text { bronchiolitis obliterans } \\
\text { organizing pneumonia }\end{array}$ & Concomitant & Active \\
\hline Diamantino F, et al. [29] & 2011 & 1 & 79/M & Myelodysplastic syndrome & Sweet's syndrome & 15 months after & Remission \\
\hline Castrejón I, et al. [30] & 2007 & 1 & $67 / M$ & Lymphoplasmocytic Lymphoma & Erythema Nodosum & Concomitant & Active \\
\hline Labarthe MP, et al. [31] & 1997 & 1 & $-/ M$ & Prostatic adenocarcinoma & - & - & - \\
\hline Calistru AM, et al. [32] & 2011 & 1 & $71 / \mathrm{M}$ & Myelodysplastic syndrome & Sweet's syndrome & 3 years before & - \\
\hline Bochtler T, et al. [33] & 2005 & & $60 / \mathrm{M}$ & chronic lymphocytic leukaemia & - & Concomitant & - \\
\hline Van Besien $\mathrm{K}$, et al. [34] & 1992 & 1 & - & Myelodysplastic syndrome & - & Concomitant & Active \\
\hline Myers B, et al. [35] & 2000 & 2 & $\begin{array}{l}82 / \mathrm{M} \\
59 / \mathrm{M}\end{array}$ & Myelodysplastic syndrome & - & $\begin{array}{l}8 \text { months after } \\
2 \text { months after }\end{array}$ & Active disease \\
\hline McAdam LP, et al. [38] & 1976 & $1 / 23$ & - & Myelomonocytic leukemia & - & - & - \\
\hline Shirota T, et al. [39] & 1993 & 1 & - & $\begin{array}{l}\text { Myelodysplastic syndrome } \\
\text { Chronic myelomonocytic leukemia }\end{array}$ & - & Concomitant & Active \\
\hline Lavabre-Bertrand T, et al. [40] & 1993 & 1 & & Chronic myelomonocytic leukemia & - & Concomitant & Active \\
\hline Magro CM, et al. [41] & 1997 & - & - & Cutaneous lymphoma & - & - & - \\
\hline Berthier S, et al. [42] & 2001 & 1 & - & Myelodysplastic syndrome & - & - & - \\
\hline Banerjee SS, et al. [43] & 2001 & 1 & $65 / \mathrm{M}$ & Myelodysplastic syndrome & - & 1 year before & \\
\hline Sterpu R, et al. [44] & 2011 & 1 & $72 / \mathrm{M}$ & Kaposi sarcoma & - & 4 years after & Remission \\
\hline
\end{tabular}


30-year-old woman. No special associated features were recorded. It was detected in our patient 12 years later and complete remission was maintained until diagnosis of neoplasm. Our patient had extensive disease with liver and lymph node metastases.

Lung cancerhas been also described in 3 cases $[4,9,22]$ (Table 1 ). Similar tumours in the breast, vocal cords, prostate [23], Kaposi sarcoma [24], soft-tissue sarcoma [25], malignant fibrohistiocytoma and urothelial carcinoma [26] have also been recorded in few cases (Table 1).

Cutaneous features have been described in $35-50 \%$ of RP patients [1]. Sweet's syndrome was associated with RP in at least 27 cases (Table 1): the most common associated neoplasm was MS [3,27-29]. Some authors presumed that Sweet's syndrome in patients with RP may initiate MS development $[27,28]$. Moreover, a variety of skin lesions occurred in malignancy-associated $\mathrm{RP}$ :dermatomyositis in one case [6], pyoderma gangrenosum has been described in one case [11], centrifugal annular erythema in one case [16] and erythema nodosa in another case [30]. Other associated conditions such as musculo-aponeurotic fibromatosis, bronchiolitis obliterans organizing pneumonia, hypothyroidism, auricular cartilage infiltration of immunoglobulin G4-positive plasma cells and thrombosis were mentioned in different cases (Table 1). Thereby, associated cutaneous lesions may be a potential predictor to further malignancy in RP patients. Our patient did not present any cutaneous manifestation.

The association of malignancy with RP does not appear incidental. There is probably a common trigger that links the two diseases. The autoimmune basis is more and more raised, but it part in the pathogenesis of paraneoplastic RP has not yet been obvious [13,31-34]. Of note, treatment may induce remission of the two diseases. Many authors suggest that the RP and cancer may be induced by a T-cell defect $[3,32,35,36]$. Hall $R$, et al. suggest that MS dendritic cells are activated and may lead to B-cell hyperplasia with abnormal antibodies production, and probable genetic error inducing neoplasm [15]. This mechanism may be sustained with the substantial associated cutaneous diseases. It is also well known that the development of RP is strongly associated with human leucocyte antigen HLA-DR4 $[3,35,36]$. A link between HLA antigen variants and development of colorectal cancer [37] and hematological disorders [2] was established. In addition, the inflammation of colorectal stroma and connective tissue may be the main substratum of the 2 diseases [21]. Furthermore, it is possible that the interaction between immunosuppressive drugs and T-cells could lead to the development of neoplastic disorders [24]. Our review of the literature showed that the RP were mostly treated with only steroid therapy, associated in few 4 cases with Cyclophosphamide in 3 cases, Azathioprin in 2 cases and Methotrexate in other 2 cases, Cyclosporin A in 2 cases and Chlorambucil in 1 case (Table 1). Our patient was treated at diagnosis of CC with only Prednisone: $10 \mathrm{mg} /$ day. These results may move apart the part of immunosuppressive therapy in its pathogenesis.

Until RP may be associated with ulcerative colitis and Crohn disease in few reports [1,3], we might search colorectal cancer. Nevertheless, our review showed only one case associated with nonspecific colitis [13], unlike our case.

Given the missing data, 11 patients died and no relapse ofRP occurred in 7 cases. The most reason of death was infection (Table 1). The disease tended to show improvement with therapy of the malignancy. Surgical resection was accomplished in our patient with no relapse of RP.

We suggest that patients with RP should be screened for occult cancer, including a thorough history and physical examination, laboratory and radiological investigations. The patients with RP should be monitored more carefully even in remission for early detection of cancer.

\section{Competing Interests}

The authors declare no competing interest.

\section{References}

1. Cantarini L, Vitale A, Brizi MG, Caso F, Frediani B, et al. (2014) Diagnosis and classification of relapsing polychondritis. J Autoimmun 48-49: 53-59.

2. Cohen PR (2006) Granuloma annulare, relapsing polychondritis, sarcoidosis, and systemic lupus erythematosus: conditions whose dermatologic manifestations may occur as hematologic malignancy associated mucocutaneous paraneoplastic syndromes. Int J Dermatol 45: 70-80.

3. Puéchal X, Terrier B, Mouthon L, Costedoat-Chalumeau N, Guillevin L, et al. (2014) Relapsing polychondritis. Joint Bone Spine 81: 118-124.

4. Michet CJ Jr, McKenna CH, Luthra HS, O'Fallon WM (1986) Relapsing polychondritis. Survival and predictive role of early disease manifestations. Ann Intern Med 104: 74-78.

5. Diebold L, Rauh G, Jäger K, Löhrs U (1995) Bone marrow pathology in relapsing polychondritis: high frequency of myelodysplastic syndromes. $\mathrm{Br} \mathrm{J}$ Haematol 89: 820-830.

6. Francès C, EIRassi R, Laporte JL, Rybojad M, Papo T, et al. (2001) Dermatologic Manifestations of Relapsing Polychondritis. A Study of 200 Cases at a Single Center. Medicine 80: 173-179.

7. Hebbar M, Brouillard M, Wattel E, Decoulx M, Hatron PY, et al. (1995) Asscociation of myelodysplastic syndrome and relapsing polychondritis: further evidence. Leukemia 9: 731-733.

8. Arlet P, Pris J, Sallerin F, Vilain C, Laroche M, et al. (1989) Chronic relapsing polychondritis. Clinical characteristics. Presse Med 18: 157-160.

9. Mongin M, Gabriel B, Weiller PJ (1988) Atrophic polychondritis and its pathologic accompaniments. Bull Acad Natl Med 172: 109-113.

10. Hamidou MA, Derenne S, Audrain MA, Berthelot JM, Boumalassa A, et al. (2000) Prevalence of rheumatic manifestations and antineutrophil cytoplasmic antibodies in haematological malignancies. A prospective study. Rheumatology 39: 417-420.

11. Hedayati H, Zuzga JJ Jr, Faber DB (1993) Rheumatoid arthritis, relapsing polychondritis, and pyoderma gangrenosum evolving into non-Hodgkin's lymphoma. J Am Osteopath Assoc 93: 246-248.

12. Lichauco JJ, Lauer S, Shigemitsu HH, Bello JA, Bhattacharyya PK, et al. (2001) Orbital Mucosa-Associated Lymphoid Tissue (MALT)-Type lymphoma in a patient with relapsing polychondritis. Arthritis Rheum 44: 1713-1715.

13. Yanagi T, Matsumura T, Kamekura R, Sasaki N, Hashino S (2007) Relapsing polychondritis and malignant lymphoma: is polychondritis paraneoplastic? Arch Dermatol 143: 89-90.

14. (1997) Case records of the Massachusetts General Hospital. Weekly clinicopathological exercises. Case 38-1997. Inflammation of the ears, anemia, and fever 21 years after treatment for Hodgkin's disease. $\mathrm{N}$ Engl J Med 337: 1753-1760.

15. Hall R, Hopkinson N, Hamblin T (2000) Relapsing polychondritis, smouldering non-secretory myeloma and early myelodysplastic syndrome in the same patient: three difficult diagnoses produce a life threatening illness. Leuk Res 24: 91-93.

16. Morell S, Lambert M, Philippe P, Queyrel V, Michon-Pasturel U, et al. Centrifugal annular erythema and polychondritis: paraneoplastic manifestations of myeloma.

17. Miller SB, Donlan CJ, Roth SB (1974) Hodgkin's disease presenting as relapsing polychondritis. A previously undescribed association. Arthritis Rheum 17: 598-602.

18. Zeuner M, Straub RH, Rauh G, Albert ED, Schölmerich J, et al. (1997) Relapsing polychondritis: clinical and immunogenetic analysis of 62 patients. J Rheumatol 24: 96-101.

19. Jouanique C, Herreman G (1989) Chronic atrophic polychondritis associated with cancer. Presse Med 18: 1080

20. Quinsat D, Harlé JR, Durand JM, Weiller PJ, Mongin M (1989) Relapsing polychondritis and cancer. 2 cases. Ann Med Interne (Paris) 140: 422-423.

21. Gning SB, Perret JL, Cissokho B, Sane M, Ndoye B (2001) Atrophic polychondritis associated with rectal adenocarcinoma and muscular aponeurotic fibromatosis in an African woman. Rev Med Interne 22: 891-893.

22. Horai Y, Miyamura T, Arase H, Kimura D, Shimada K, et al. (2011) A case of relapsing polychondritis associated with auricular cartilage infiltration of immunoglobulin G4-positive plasma cells and lung cancer. Mod Rheumatol 21: $557-560$.

23. Odkvist L (1970) Relapsing polychondritis. Acta Otolaryngol 70: 448-454.

24. Manghani MK, Andrews J, Higgens CS (2004) Kaposi's sarcoma in a patient with severe relapsing polychondritis. Rheumatol Int 24: 309-311.

25. Fransen HR, Ramon FA, De Schepper AM, De Beuckeleer LH, Bal J, et al. (1995) Chondrosarcoma in a patient with relapsing polychondritis. Skeletal Radiol 24: 477-480. 
26. Astudillo L, Launay F, Lamant L, Sailler L, Bazex J, et al. (2004) Sweet's syndrome revealing relapsing polychondritis. Int J Dermatol 43: 720-722.

27. Washio K, Oka M, Ohno K, Shimizu H, Kawano S, et al. (2012) Case of recurrent Sweet's syndrome in a patient with relapsing polychondritis and myelodysplastic syndrome. J Dermatol 39: 731-733.

28. Kawakami T, Kawase A, Takeuchi S, Yoshioka S, Fujimoto N, et al. (2008) Sweet syndrome subsequent to relapsing polychondritis and myelodysplastic syndrome in a Japanese patient. Acta Derm Venereol 88: 517-519.

29. Diamantino Fda E, Raimundo PM, Fidalgo Al (2011) Sweet's Syndrome and relapsing polychondritis signal myelodysplastic syndrome. An Bras Dermatol 86: S173-S177.

30. Castrejón I, Ibáñez M, Vicente E, Luis Steegmann J, Castañeda S (2007) Relapsing polychondritis associated with a lymphoplasmocytic lymphoma and erythema nodosum. Reumatol Clin 3: 45-47.

31. Labarthe MP, Bayle-Lebey P, Bazex J (1997) Cutaneous Manifestations of Relapsing Polychondritis in a Patient Receiving Goserelin for Carcinoma of the Prostate. Dermatology 195: 391-394.

32. Calistru AM, Lisboa C, Azevedo F (2011) Paraneoplastic relapsing polychondritis and Sweet syndrome coexisting in a patient with myelodysplasia. Indian J Dermatol Venereol Leprol 77: 730.

33. Bochtler T, Hensel M, Lorenz HM, Ho AD, Mahlknecht U (2005) Chronic lymphocytic leukaemia and concomitant relapsing polychondritis: a report on one treatment for the combined manifestation of two diseases. Rheumatology 44: 1199.

34. Van Besien K, Tricot G, Hoffman R (1992) Relapsing polychondritis: a paraneoplastic syndrome associated with myelodysplastic syndromes. Am J Hematol 40: 47-50.
35. Myers B, Gould J, Dolan G (2000) Relapsing polychondritis and myelodysplasia: a report of two cases and review of the current literature. Clin Lab Haematol 22: 45-48.

36. Arnaud L, Mathian A, Haroche J, Gorochov G, Amoura Z (2014) Pathogenesis of relapsing polychondritis: a 2013 update. Autoimmun Rev 13: 90-95.

37. Altomonte M, Fonsatti E, Visintin A, Maio M (2003) Targeted therapy of solid malignancies via HLA class II antigens: a new biotherapeutic approach? Oncogene 22: 6564-6569.

38. McAdam LP, O'Hanlan MA, Bluestone R, Pearson CM (1976) Relapsing polychondritis: prospective study of 23 patients and a review of the literature. Medicine (Baltimore) 55: 193-215.

39. Shirota T, Hayashi O, Uchida H, Tonozuka N, Sakai N, et al. (1993) Myelodysplastic syndrome associated with relapsing polychondritis: unusual transformation from refractory anemia to chronic myelomonocytic leukemia. Ann Hematol 67: 45-47.

40. Lavabre-Bertrand T, Navarro M (1993) Relapsing polychondritis and myelodysplastic syndrome. Am J Hematol 43: 243.

41. Magro CM, Crowson AN, Harrist TJ (1997) Atypical lymphoid infiltrates arising in cutaneous lesions of connective tissue disease. Am J Dermatopathol 19: 446-455.

42. Berthier S, Magy N, Gil H, Schneider MB, Vuitton DA, et al. (2001) Myelodysplasias and systemic diseases. A non-fortuitous association. Rev Med Interne 22: 428-432.

43. Banerjee SS, Morris DP, Rothera MP, Routledge RC (2001) Clinical Records Relapsing polychondritis associated with monoclonal gammapathy in a patient with myelodysplastic syndrome. J Laryngol Otol 115: 482-484.

44. Sterpua R, Mancerona V, Grossinb M, Voitel D, Mahéc E, et al. (2012) Kaposi's sarcoma in a case of relapsing polychondritis. Rev Med Interne 33: 114. 